\title{
HETEROLOGOUS EXPRESSION OF A CHITINASE GENE FROM AEROMONAS CAVIAEIN PSEUDOMONAS FLUORESCENS
}

\author{
AMARILA MAHK ${ }^{\mathrm{U}^{+}+}$, ANTONIUS SUWANTO ${ }^{12+2}$ ", BUDI TJAHJONO ${ }^{3}$, ROB HARLING ${ }^{4}$ \\ 'Southeast Asian Regional Center for Tropical Biology (SEAMEO BIOTROP), Bogor, \\ ${ }^{2}$ Department of Biology, Faculty of Mathematics and Sciences, ${ }^{3}$ Department of Plant Pests \\ and Diseases, Faculty of Agriculture, Bogor Agricultural University, \\ Bogor-16144, Indonesia: ' \\ 'Department of Crop Science. Scottish Agricultural College, Edinburgh EH9 3JG, UK.
}

\begin{abstract}
A transcriptional fusion for an Aeromonas caviae chitinase gene was constructed under the control of a constitutive promoter of the kanaraycin resistance gene $\left(\mathrm{PKm}^{\mathrm{R}}\right)$. The construct was inserted into a medium copy number broad host range plasmid vector to yield recombinant plasmid pAM340, which harbored transcriptional fusion $\mathrm{PKm}^{\mathrm{R}}$ - chi. Another transcriptional fusion, Ptac-chi, in a recombinant plasmid pAM630, was conducted as comparison. Triparental mating of $E$. coli carrying the recombinant plasmids with Pseudomotws fluorescens 5100, a phyllosphere bacterium, was performed. Pseudomonas fluorescens 5100 exconjugants were examined for constitutive expression of chitinase employing a spectrophotometric assay; they showed stronger chitin degradation activity than Escherichia coli transformants. Using a fungal antagonism plate assay, this chitinolytic $P$. fluorescens, however, could not inhibit selected phytopathogenic fungi.
\end{abstract}

Keywords: Aeromonas caviae/ chitinase gene/transcriptional fusion/PKm'V Vtac-chilPseudomonas fluorescens

\section{INTRODUCTION}

Chitinase is an enzyme that catalyzes the hydrolysis of chitin to oligomers. Chitin is an insoluble linear p-1, 4-linked unbranched polymer of 7V-acetylgluco-samine, and is a major constituent of fungal cell wall. Chitinase is found widely distributed amongst many organisms, but its physiological role is different among them.

In chitinase-producing plants, this enzyme is used for self-defense against plant pathogens and pests, i.e. to hydrolyse chitin in the cell wall of certain fungal pathogens and cuticle of pests (Boiler et al. 1983; Hedrick et $a$ ।. 1988; Oppenheim and Chet 1992). It has been suggested that chitinase production in plants is induced by microbial infections or other injuries (Hedrick et al. 1988). In chitinase-producing bacteria, extracellular chitinases are produced to digest chitin and utilize

* Author to whom all correspondence and reprint requests should be addressed : Tel : +62 (251)

625965; Fax:+62 (251) 315107 ; E-mail : asuwanto@indo.net.id + Present address : Department of Pharmacy, Faculty

of Mathematics and Natural Sciences, University

oflndonesia. 
BIOTROPIA No. 20,2003

it primarily as a carbon and energy source (Gooday 1990). The exploration and utilization of bacterial chitinase in plant protection is centred around its use to protect against pathogenic fungi as a biocontrol mechanism. This potential has been a major concern in constructing biocontrol agents against fungi. Several studies regarding this have been reported (Inbar and Chet 1991; Koby et al. 1994).

We have cloned and sequenced a heterogenous chitinase gene (chi) from a soilborne Aeromonas caviae isolated from a blackpepper plantation in Bangka Island, Indonesia in our previous study ( Malik et al. In press). This gene has $97 \%$ identity with the chitinase gene chiA from A. caviae (UO9139) (Sitrit et al. 1995). In this present study, we intended to utilize this gene under control of a constitutive promoter, i.e. the kanamycin resistance gene from Tn903, in a suitable vector for expression in a phyllosphere bacterium, as a means of producing a chitinolytic biocontrol agent. We cloned this chi gene into a relatively small size and medium copy number broad host range plasmid vector, pBBRIMCS-2 (Kovach et al. 1994), rather than into a high copy number plasmid as reported by Koby et al. (1994). This strategy was employed to avoid accumulation of defective Escherichia coll mutants during high expression of chitinase (Koby et al. 1994). Therefore, the aim of this work was to construct a chitinolytic $P$. fluorescens biocontrol strain through the introduction of a chitinase gene under the control of the $\mathrm{Km}^{\mathrm{R}}$ promoter as a transcriptional fusion $\left(\mathrm{PKm}^{\mathrm{R}}-\mathrm{c} / \mathrm{j}\right)$.

\section{MATERIALS AND METHODS Bacterial}

\section{strains, plasmids, and growth conditions}

Bacterial strains and plasmids used or constructed during this study are described in Table 1. E. coli strains which were used as hosts for cloning experiments throughout this study, and their derivatives also, were routinely grown in Luria Bertani (LB) medium (broth or solidified with $1.5 \%$ agar) at $37^{\circ} \mathrm{C}$ for 18 hours. Ampicillin $(100 \mathrm{ng} / \mathrm{ml})$, kanamycin $(25 \mu \mathrm{g} / \mathrm{ml})$, trimethoprim $(100 \mu \mathrm{g} / \mathrm{ml})$ and gentamycin $(10 \mu \mathrm{g} / \mathrm{ml})$ were added to the growth media when needed. Pseudomonas fluorescens strains were grown routinely in King's B (KB) 10\% agar (King et al. 1954 ) at $25^{\circ} \mathrm{C}$ for $18-20$ hours. Spontaneous rifampicin resistant mutants (Rii ) of P. fluorescens, which was done according to the method described by Eisenstadt et al. (1994), were isolated by plating a $25 \mathrm{uL}$ aliquot of a 10 -fold concentration of a stationary phase culture onto plates containing a gradient concentration from 10 to $100 \mathrm{ug} / \mathrm{ml}$ of rifampicin.

\section{DNA manipulation}

Plasmid DNAs were isolated either by alkaline lysis (Sambrook et al. 1989), or hv DNA nurification kits (Promeea Wis.. or BioRad, Richmond, Calif.). Restriction 
Heterologous expression of a chitinase gene from Aeromonas caviae - Amarila Malik el al

Table 1. Bacterial strains and Piasmids

\begin{tabular}{|c|c|c|}
\hline \multicolumn{2}{|c|}{ Bacterial strains and plast Relevant characteristics } & \multirow[t]{2}{*}{ Reference or source } \\
\hline E. coli & & \\
\hline DH5a & F", for a-complementation, general host for cloning & $\begin{array}{l}\text { Samhhnnk ot } \\
\text { al. } 1989\end{array}$ \\
\hline TOP10 & F", for a -complementation, general host for cloning & Invitrogen, Inc. (Carlsbad, Calif.) \\
\hline HB101(pRK2013) & mod" Res", general helper strain for bacterial conjugation & Dittae/fl/1980 \\
\hline TOP10(pAM340) & TOP10 carries fusion transcription $\mathrm{PKm}^{\mathrm{R}}$-ci; & This study \\
\hline TOP10(pAM630) & TOP10 carries fusion transcription Ptac-chi & This study \\
\hline \multicolumn{3}{|l|}{ P.jluorescens } \\
\hline 5100 & Phyllosphere biosurfactant* strain, wildtype, derived from & Campbell et al \\
\hline 5100 Rif & $\begin{array}{l}\text { Brassica oleracea var italica } \\
\text { Spontaneous rifampicin resistance mutant PfSIOO }\end{array}$ & $\begin{array}{l}1995 \\
\text { This study }\end{array}$ \\
\hline 5100(pAM340) & Pf 5100 (Rif) carries fusion transcription $\mathrm{PKm}^{\mathrm{R}}$-c/i; & This study \\
\hline 5100(pAM630) & Pf 5100 (Rif) carries fusion transcription Ptac-chi & This study \\
\hline Aeromonas caviae $\mathrm{W}$ & I Chitinolytic, wildtype & Malik etal In press \\
\hline \multicolumn{3}{|l|}{ Plasmids } \\
\hline pUC19 & lacZ. $\mathrm{Ap}^{\mathrm{R}}$ cloning vector & Sambrook et al. 1989 \\
\hline PAS385 & $\begin{array}{l}\text { MCS from pSL301(£coRI-.eo/I) cloned into pUC19 } \\
\text { (Smal-EcoRl), } \mathrm{Ap}^{\mathrm{R}}\end{array}$ & $\begin{array}{l}\text { Suwanto \& Kaplan } \\
1992\end{array}$ \\
\hline pAS396 & Source of trimethoprim resistance gene $\left(\mathrm{Tp}^{\mathrm{R}}\right)$ in pAS385 & Suwanto \& Kaplan 1992 \\
\hline pBBRIMCS-2 & Broad-host range, medium copy number, $\mathrm{Km}^{\mathrm{R}}$ & Kovache/a/. 1994 \\
\hline pUC4K & $\mathrm{PKm}^{\mathrm{R}}$ source, $\mathrm{Km}^{\mathrm{R}}$ gene from $1 \mathrm{n} 903$ & OknetaL 1981 \\
\hline p34S-Gm & Source of gentamycin resistance gene $\left(\mathrm{Gm}^{\mathrm{R}}\right)$ & Dennis \& Zylstra 1998 \\
\hline pWS506 & pAS385 carrying $2.9 \mathrm{~kb}$ Xhol + ffmdlU chitinase gene & Malik et aL In \\
\hline pAM201 & $\begin{array}{l}\text { fragment from A. caviae WS7b } \\
\text { c/i/-Tp }{ }^{\mathrm{R}} \text { DNA fragment as Sail cassette in pAS385 }\end{array}$ & $\begin{array}{l}\text { Press } \\
\text { This study }\end{array}$ \\
\hline pAM330 & PKnf-chi in pBBRIMCS-2, $\mathrm{Tp}^{\mathrm{R}}$ & This study \\
\hline pAM340 & $\mathrm{PKm}^{\mathrm{R}}$-c/i/ in pBBRIMCS-2, Tp", $\mathrm{Gm}^{\mathrm{R}}$ & This study \\
\hline pAM630 & Ptac-chi in pBBRIMCS-2, Gm ${ }^{\mathrm{R}}$ & This study \\
\hline
\end{tabular}

fragments were purified from agarose gels with the Gene Clean kit (BiolOl Inc., La Jolla, Calif.). DNA filled-in reaction, utilizing T4 DNA Polymerase (Boehringer Mannheim Biochemicals, Indianapolis, Ind.), DNA fragment ligations, recombinant DNA transformation, and other accessory techniques were carried out as described by Sambrook et al (1989). Escherichia coli transformants harboring the chitinase recombinant were selected on LB-chitin agar plates, supplemented with the appro- 
ing $\mathrm{PKm}{ }^{\mathrm{R}}$, as well as Ptac, were selected by a blue-white assay on LB agar plates, containing IPTG (0.5mM), and X-Gal (5-bromo-4-chloro-3-indolyl-b-d-thiogalacto-pyranoside) $40 \mathrm{mg} / \mathrm{ml}$. Plasmids were maintained by selection in the presence of appropriate antibiotics.

\section{Bacterial Conjugation}

Recombinant plasmids $\mathrm{PKm}^{\mathrm{R}}$-c/» and Ptac-chi were introduced into P. fluorescens 5100 (Campbell et al. 1995) by bacterial conjugation as described by Ditta et al (1980). Triparental mating was performed, employing E. coli HB101 (pRK2013) (Ditta et al. 1980) as helper, E. coli TOP10 (pAM340), as well as E. coli TOP10 (pAM630), as donor, and P. fluorescens 5100 Rif as recipient. The cells of all bacteria employed in this mating were collected from mid-exponential phase cultures, harvested by centrifiiging recipient, donor, and helper cultures in a ratio of 8:1:1, washing the pellet twice in sterile saline solution, and resuspending in a small volume of LB broth (30 ul). All cell suspensions were mixed, spotted onto LB agar plates without any antibiotic supplements, and incubated at $25^{\circ} \mathrm{C}$.

\section{Polymerase Chain Reactions}

Standard PCR reactions were performed to verify the presence of cloned chi in P. fluorescens exconjugants, followed by electrophoretic analysis. An approximately 800-bp fragment of chi (accession number AJ431785) was amplified in a GeneAmp 2400 thermal cycler (Perkin Elmer). Single colonies of exconjugants were resus-pended into a reaction mixture prepared with TaqDNA polymerase (FINNZYME). The thermocycling program used in this study consisted of denaturation at $94{ }^{\circ} \mathrm{C}$ for $60 \mathrm{~s}$, annealing at $54^{\circ \circ} \mathrm{C}$ for $60 \mathrm{~s}$, and elongation at $72{ }^{\circ} \mathrm{C}$ for $90 \mathrm{~s}$, for $25 \mathrm{cycles}$, as a modification of the method described in Chernin et al. (1997). A set of chi internal primers, which were designed based on $A$. caviae chitinase DNA sequence (accession number AJ431785), were used, i.e. forward primer 5 ' - G T G A A G A A C T A C C A G G C -3', and reverse primer 5 ' G G C A G A T C A G T T G C A G C T C G -3' (GENSET Biotech, Singapore).

\section{Chitinase Plate Assay and Semimicro-quantitative Assay}

An assay for chitinase was carried out on LB agar supplemented with colloidal chitin 1\% (Hsu and Lockwood 1975) for $E$. coli derivatives, whilst for $P$. fluorescens derivatives this was carried out on $10 \% \mathrm{~KB}$ agar supplemented with colloidal chitin at the same amount. P. fluorescens exconjugants were selected on $10 \% \mathrm{~KB}$ agar supplemented with rifampicin $(50 \mathrm{ug} / \mathrm{ml})$ and gentamycin after introducing transcriptional fusion recombinant plasmids by bacterial conjugation.

Semimicro-quantitative assay was performed as described previously (Malik et a/. In press). Cultures of the recombinant bacteria were collected after growing for 18-20 hours both for $E$. coli and $P$. fluorescens, whilst cultures of $A$. caviae were 
Heterologous expression of a chitinase gene fromAeromonas caviae - Amarila Malik et al.

collected from 15 hours. Enzyme activity was measured in both extracellular and intracellular fractions, after sonicated the cell. The protein concentration was measured according to the method as described by Bradford (1976). Chitinase activity was assayed by a modification of methods as described using colloidal chitin azure as substrate (Wirth and Wolf 1990; Evrall et al. 1990; Hood 1990). The amount of dye released from this chromogenic substrate, remazol brilliant blue, was measured at $590 \mathrm{~nm}$. A standard curve was constructed using a chitinase standard from Streptomyces griseus (Sigma Chemical, St. Louis, Mo) against colloidal chitin azure as substrate, in citrate-phosphate buffer $\mathrm{pH} 6.0$ as described by Hood (1990), and incubation temperature $37^{\circ} \mathrm{C}$ for 2 hours. The enzymatic activity was expressed as units of chitinase/mg of protein.

\section{Assay for Antagonism to Fungi}

An antagonism assay was performed as described by Chernin et al. (1995): Test bacteria were grown for 24 and $48 \mathrm{~h}$ for $A$. caviae WS7b (Malik et al. In press) and $P$. fluorescens strains, respectively, in Luria or nutrient broth at $30^{\circ} \mathrm{C}$ with aeration. The suspension of cells was streaked in a line at the centre of a PDA plate and incubated at $30{ }^{\circ} \mathrm{C}$ for 24 and $48 \mathrm{~h}$ for WS7b and $P$. fluorescens strains, respectively. After placing 3-mm diameter agar disks of an actively growing fungal culture of either Botrytis cinerea TOM98LD and Fusarium solani $f$. sp. pisi, at 3 to $4 \mathrm{~cm}$ away from each side of the bacterial growth area, the plates were incubated for 3 to 25 days, until mycelium growing from the two sides on a control plate came into contact.

\section{RESULTS Construction}

\section{of Sail-cassette ofchi}

Constitutive promoter of kanamycin resistance gene $\left(\mathrm{PKm}^{\mathrm{R}}\right)$ from $T n 903$ used in this study possesses a unique restriction site, Xhol (Oka et al. 1981). This Xhol site was employed to construct a transcriptional fusion of $A$. caviae WS7b chitinase gene chi (accession number AJ431785) under the control of PKm ${ }^{\mathrm{R}}$ (Fig.l). The chi gene in pWS506 was cloned without its indigenous promoter (Malik et al. In press).

Plasmid pAM201-A carrying a Sail cassette of chi was constructed through several intermediate-cloning steps (Fig. 1). The first step was the insertion of trimethoprim resistance gene $\left(\mathrm{Tp}^{\mathrm{R}}\right.$ ) isolated from pASS 96 (Suwanto and Kaplan 1992), as a marker downstream ofchi fragment at Hpal site in pWS506. The chi- $\mathrm{Tp}^{\mathrm{R}}$ fragment was then isolated subsequently employing $\mathrm{HindHI}+\mathrm{EcoRV}$ double digestion. The protruding end of Hinalll was made blunt by means of T4 DNA polymerase to obtain blunt end $c h i-T p^{R}$ fragment, which was then ligated with blunt-end Hpal of vector pAS385 (Suwanto and Kaplan 1992), generated recombinant plasmid pAM201 (Fig 1). Plasmid pAM201-A carries $\mathrm{c} / \mathrm{z} /-\mathrm{To}^{\mathrm{R}}$ 
A

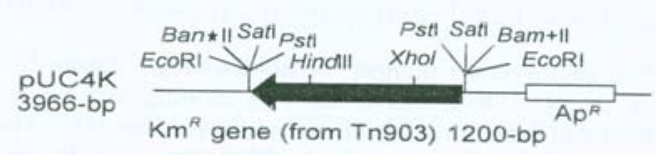

$\boldsymbol{B}$
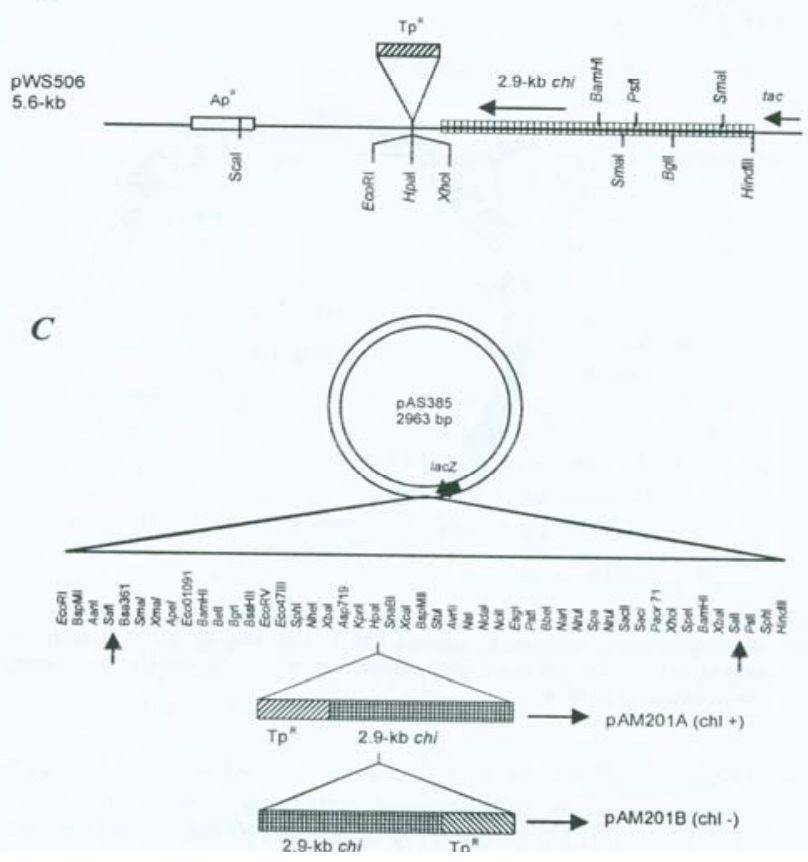

Figure 1. Schematic structure of Sail cassette construction of chi. The promoter of kanamycin resistance gene $\left(\mathrm{PKm}^{\mathrm{R}}\right)$ from Tn903 in pUC4K is located upstream of the $\mathrm{Xhol}$ site (Oka et a/,1981) (A). A trimethoprim resistance gene (Tp ${ }^{\mathrm{R}}$ ) fragment, isolated from pAS396 (Suwanto \& Kaplan 1992), was inserted downstream of the chi fragment in pWS506 (Malik et al. In press) as marker at Hpal site in polyl inker site (B). The c/i/- $\mathrm{Tp}^{\mathrm{R}}$ fragment was isolated employing Hindlll+ EcoRV double digestion. The protruding end of IfiruH.ll was made blunt, which was then ligated with blunt-end Hpal end of linearized vector pAS385 (Suwanto \& Kaplon 1992), resulting in recombinant plasmids pAM201-A (chi+) and pAM201-B (chi-) that carry Sail cassette of c/i;-Tp ${ }^{\mathrm{R}}$ (C). 

Heterologous expression of a chitinase gene from Aeromonas caviae - Amarila Malik et al.

\section{Construction of $P \mathrm{Km}^{R}$-chi transcriptional fusion in pBBRIMCS-2}

A medium copy number broadhost-range plasmid vector, pBBRIMCS-2 (Kovach et al. 1994), was utilized as cloning vehicle to introduce $P K m^{R}$-chi transcriptional fusion into Pseudomonas fluorescens 5100. The $\mathrm{c} / \mathrm{m} / \mathrm{Tp}^{\mathrm{R}}$ Sail cassette from pAM201-A was inserted into Xhol site of pBBRIMCS-2 under $\mathrm{PKm}^{\mathrm{R}}$ to generate pAM330, in which $\mathrm{c} / »^{\prime}-\mathrm{Tp}^{\mathrm{R}}$ will be transcribed under control of $\mathrm{Km}^{\mathrm{R}}$ promoter (Fig 2).

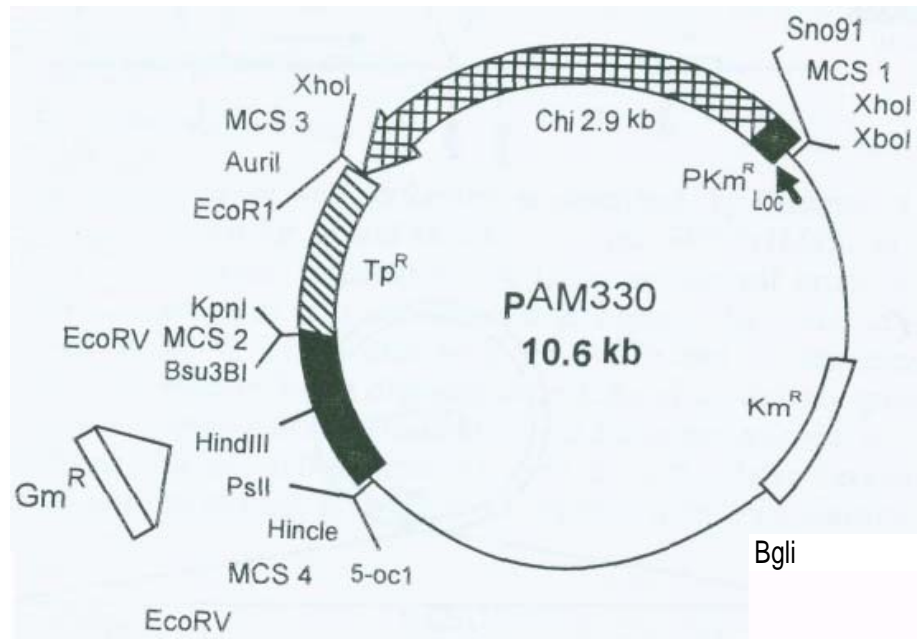

Figure 2. Restriction map of recombinant plasmid pAM330 carrying $\mathrm{PKm}^{\mathrm{R}}-\mathrm{c} / \mathrm{i}$; transcriptional fusion in pBBRIMCS-2. The additional $\mathrm{Gm}^{\mathrm{R}}$ marker was inserted at ///«dIII site downstream of $\mathrm{Tp}^{\mathrm{R}}$, which generated pAM340

In addition to $\mathrm{Tp}^{\mathrm{R}}$ marker, a $\mathrm{Gm}^{\mathrm{R}}$ cassette isolated from p34S-Gm (Dennis and Zylstra 1998) was used as an alternative marker by inserting the cassette downstream of $\mathrm{Tp}^{\mathrm{R}}$ resulting in pAM340 (Fig 2), since $\mathrm{Tp}^{\mathrm{R}}$ marker was not sufficient to select for Pf exconjugants after mobilizing pAM330 from the E. coli transformant.

\section{Construction of Ptac-chi transcriptional fusion in pBBRIMCS-2}

A BamHl fragment of Ptac isolated from pKK223-3 was inserted into BamHl site in pBBRIMCS-2, generating plasmid pAM601. Chitinase gene chi, which was isolated from pAM202 as Hindlll-EcoRl c/i/-Gm ${ }^{\mathrm{R}}$ fragment, was inserted subsequently into this plasmid vector, resulting in recombinant transcriptional fusion plasmid harboring Ptac-chi, designated as pAM630 (Fig 3). Plasmid pAM202 was generated from pAM201-B by replacing $\mathrm{Tp}^{\mathrm{R}}$ with $\mathrm{Gm}^{\mathrm{R}}$. 
BIOTROPIA No. 20. 2003

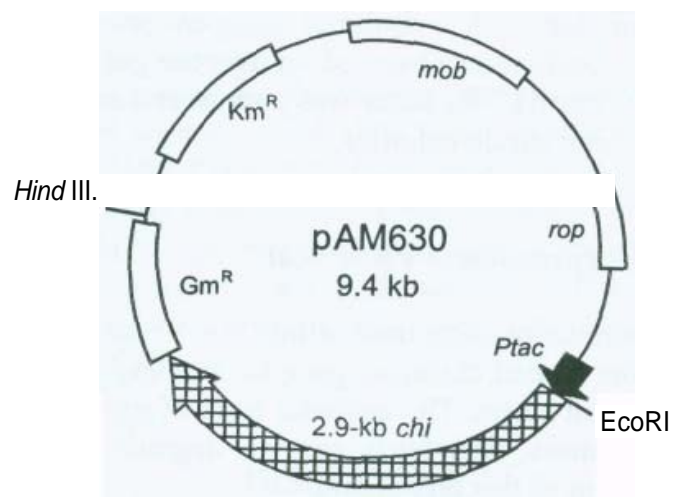

Abbreviations : Km" = Kanamycin resistance gene; $\mathrm{PKm}^{\mathrm{R}}=$ Promotor of Kanamycin resistance gene; $\mathrm{Ap}^{\mathrm{R}}=$ Ampicillin resistance gene; Tp" = Trimethoprim resistance gene; $\mathrm{Gm}^{\mathrm{R}}$ = Gentamycin resistance gene; chi = chitinase gene

Figure 3. Restriction map of recombinant plasmid pAM630 carrying ftac — chi transcriptional fusion in ${ }_{\mathrm{P}} \mathrm{BBR}$ MCS-2

\section{Chitinase expression of transcriptional fusions in E. coli and P. fluorescens.}

Screening of E. coli transformants harboring pAM340, or pAM630 on chitin agar plate showed only weak clearing zones observed after 7 and 11 days of incubation, respectively (Table 2). On the other hand, E. coli harboring pWS506 showed strong clearing zones after only 3 days of incubation.

Table 2. Chitinolytic expression of chi on chitin agar plates.

\begin{tabular}{llcl}
\hline Strains & $\begin{array}{c}\text { Expression } \\
\text { control }\end{array}$ & $\begin{array}{c}\text { Chitinolytic activity } \\
\text { as clearance zone* }\end{array}$ & $\begin{array}{c}\text { Incubation time } \\
\text { (days) }\end{array}$ \\
\hline E. co//TOP10(pWS506) & Plac & +++ & 3 \\
E. co//TOP10(pAM340) & $\mathrm{PKm}^{\mathrm{R}}$ & + & 7 \\
E. co//TOP10(pAM630) & $\mathrm{Ptoc}^{\mathrm{R}}$ & + & 11 \\
$P$. fluorescens 5100 (pAM340) & $\mathrm{PKm}^{\mathrm{R}}$ & ++ & 7 \\
P. fluorescens 5100 (pAM630) & Ptoc & ++ & 11 \\
\hline
\end{tabular}

* Relative chitin degradation ability was indicated as +, ++ and +++ for slightly, moderate, and very clear zone, respectively.

Plasmid pAM340 and pAM630 were mobilized into spontaneous rifampicin resistance (Rif) mutants of strain Pf5100. Screen ino fnr pf phitmr.Krf;/- 
selection, in conjunction with PCR techniques using chi primers as described above. Approximately 800 bp bands were observed on agarose gel after electrophoresis of exconjugants (data not shown). The latter was a rapid and easy method to verify the exconjugants after isolating single colonies.

\section{Constitutive chitinase expression of $P \mathrm{Km}^{R}$-chi}

The modified chitin azure assay used in this study could demonstrate the constitutive expression of the cloned chitinase gene by growing the E. coli recombinant and Pf exconjugant without chitin. The colloidal form of chitin azure, which consists of oligomers and monomers, was fairly easy to degrade by chitinolytic activity compared to the flake form of this compound.

We also constructed a transcriptional fusion of the same chitinase gene under the tac promoter (Fig. 3), in order to compare the promoter activity. Expression assays of both transcriptional fusions were carried out under uninduced growing conditions. The result showed that constitutive expression of chi under $\mathrm{PKm}^{\mathrm{R}}$ was slightly stronger (Tables 2 and 3). By comparing chitinolytic activity of these two P. fluorescens 5100 exconjugants to the wild type bacterium A. caviae WS7b (the origin of chi gene in this study), it could be demonstrated that constitutive chitinolytic activity of these two strains of $P$. fluorescens were less active. This is consistent with the result of our previous study on E. coli recombinant harboring chi of WS7b in a pUC vector that WS7b presumably carries more than one chitinase gene, and has a complex regulation of chitinase gene expression.

Table 3. Chitinase activity assay

\begin{tabular}{lll}
\hline \multirow{2}{*}{ Strains } & \multicolumn{2}{c}{ Chitinase assay (unit/mg protein) } \\
\cline { 2 - 3 } & Extracellular & Intracellular \\
\hline A. caviae WS7b & $7.70 "$ & $\mathrm{ND}$ \\
E. CO//TOP10 & 0.29 & 0.41 \\
E. co//TOP10(pWS506) & 2.31 & 4.17 \\
Eco/iTOP10(pAM340) & 0.93 & 1.12 \\
E. co/;TOP10(pAM630) & 0.91 & 1.05 \\
P. fluorescens 5100 Rif" & 0.77 & 0.84 \\
P. fluorescens (pBBRIMCS-2) & 0.78 & 0.83 \\
P. fluorescens (pAM340) & 1.91 & 3.27 \\
P. fluorescens (pAM630) & 0.97 & 2.53 \\
\hline
\end{tabular}

\#as positive control,collected from90 hrs of growth incubation time ND = not determined 
BIOTROPIA No. 20,2003

\section{Antifungal Plate Assay}

The antagonism assay of $P$. fluorescens strains harboring pAM340, and pAM630, was conducted with A. caviae WS7b as positive control for chitinolytic activity. P. fluorescens 5100 Rif and $P$. fluorescens (pBBR!MCS2) were used as negative control strains. The inhibition zones between the pathogenic fungus Botrytis cinerea TOM98LD and the tested strains were observed after 3 to 24 days of incubation. The positive control, WS7b, showed an inhibition zone up to $17 \mathrm{~mm}$. However, all bacteria strains tested did not show any fungal growth inhibition against Fusarium solani f. sp. pisi.

\section{DISCUSSION}

A transcriptional fusion of $A$. caviae chitinase gene (chi) under Kanamycin resistance gene promoter $\left(\mathrm{PKm}^{\mathrm{R}}\right)$ has been constructed. $\mathrm{Km}^{\mathrm{R}}$ gene is known to be expressed constitutively. By inserting chi under this promoter, we assume this will cause simple constitutive regulation of chi. The expression of other chitinase genes has been reported under nonindigenous promoter, Ptac (Koby et al. 1994; Downing and Thomson 2000). However, the expression of chitinase gene under the control of $\mathrm{PKm}^{\mathrm{R}}$ has previously not been reported. In this study, we demonstrated the constitutive expression of chitinase under this promoter by a simple semi micro-quantitative chromogenic assay using colloidal chitin azure as substrate. The enzyme activity was determined by measuring the amount of remazol brilliant blue dye released employing spectrophotometer.

The results from the expression of chitinase transcriptional fusion assay demonstrated that both transcriptional fusions were expressed in E. coli, and were able to degrade chitin in the medium. Longer incubation time for chitinolytic activity of pAM340 and pAM630 compared to pWS506, might be due to the influence of plasmid copy number in this expression (Table 1). Plasmid pAM340 and pAM630 were constructed on a medium copy number plasmid vector pBBRIMCS-2, while pWS506 was constructed on a high copy number plasmid vector pUCl 9.

The strategy to isolate and insert the promoters into plasmid vector pBBRIMCS-2 before fusion with chi, rather then subcloned chi under $\mathrm{PKm}^{\mathrm{R}}$ directly in pUC4K, as well as under Ptac in pKK223-3, was carried out to yield a broad host-range plasmid vector that carry a constitutive promoter $\mathrm{PKm}^{\mathrm{R}}$, as well as the strong promoter Ptac, which will be useful in future studies of other heterologous gene expressions.

The result of the semimicro-quantitative of chitinase activity assay indicated that chi was expressed constitutively both in E. coli or P. fluorescens 5100 recombinants (Table 3). However, chitinase activity of intracellular fractions were higher than the extracellular fractions which can be assumed that the chitinase product might not be well secreted in E. coli, as we have discussed in our previous study, as well as in P. fluorescens (Malik et al. In press). 
The inability of transformed $P$. fluorescens strains to slow fungal growth is more likely caused by secretion problem, as well as low expression of chitinase product in $P$. fluorescens based on the results obtained from chitinolytic expression on agar plates and semiquantitative chitinase assays as shown in Tables 2 and 3. The gene was isolated from A. caviae, and was cloned and expressed in E. coli and $P$. fluorescens, which are not indigenous hosts. Nevertheless, the fact that the protein expression machinery between these three microorganisms are not the same, could explain this low chitinolytic activity. It could be also suggested that this chitinase gene (chi) in its source bacteria A. caviae WS7b, did not act alone to slow fungal growth. It might also require other antifungal mechanisms as reported previously in Jones et al. (1986) and Sundheim et al. (1988).

\section{CONCLUSIONS}

Transcriptional fusion of the chi gene under the control of kanamycin resistance gene promoter generated constitutive expression of chitinase in both E. coli and P. fluorescens 5100, which has previously not been reported. This chitinase gene expression might be useful to be developed further for construction of a biocontrol strain to prevent the growth of phytopathogenic fungi.

\section{ACKNOWLEDGMENT}

This work was supported by Graduate Team Research Grant (URGE) Grant 029/HTPP/II/ URGE/96 to B.T., and a Higher Education LINK Award from the Department for International Development (DFID)/British Council to R.H. and A.S.

\section{REFERENCES}

Boiler, T., Gehri, A., Mauch, F. and U. Vogeli. 1983. Chitinase in bean leaves: induction by ethylene, purification, properties, and possible function. Planta 157,22-31.

Bradford, M.M. 1976. A rapid and sensitive method for the quantification of microgram quantities of protein utilizing the principle of protein-dye binding. Anal. Biochem. 72,248-254.

Campbell, L.J., Marling, R., Chard, J. and M. Sutton. 1995. Calabrese: factors controlling symptom development in bacterial spear rot. Final report, project FV104b, Horticultural Development Council, Bradbourne House, East Mailing, Kent ME 19 6DZ, UK.

Cherain, L., Z. Ismailov, S.Haran, and I. Chet. 1995. Chitinolytic Enterobacter agglomerans antagonistic to fungal plant pathogens. Appl. Environ. Microbiol. 61,1720-1726.

Chernin, L.S., de La Fuente, L., Sobolev, V., Haran, S., Vorgias, C.E., Oppenheim, A.B. and I. Chet. 1997. Molecular cloning, structural analysis, and expression in Escherichia coli of a chitinase gene from Enterobacter agglomerans. Appl. Environ. Microbiol. 63, 834 -839. 
Dennis, J.J. and G.J. Zylstra. 1998. Plasposon: Modular self-cloning minitransposon derivatives for rapid genetic analysis of Gram-negative bacterial genomes. Appl. Environ. Microbiol. 64,2710-2715.

Ditta, G., Stanfield, S., Corbin, D. and D.R. Helsinski . 1980. Broad-host range DNA cloning system for Gramnegative bacteria: construction of gene bank of Rhizobium melihti. Proc. Natl. Acad. Sci. 77,7347-7451.

Downing, K.J. and J.A. Thomson. 2000. Introduction of the Serralia marcescensa chiA gene into an endophytic Pseudomonas Jluorescens for the biocontrol of phytopathogenic fungi. Can J Microbiol 46, 363-369.

Eisenstadt, E., B. C. Carlton and B. J. Brown. 1994. Gene mutation. In: Gerhardt, P., R. G. E. Murray, W. A. Wood, N.R. Krieg (Eds). Methods for General and Molecular Bacteriology. American Society for Microbiology, Washington, D.C.: 297-315.

Evrall, C.C., Atwell, R.W., and C.A. Smith. 1990. A semi-micro quantitative assay for determination of chitinolytic activity in microorganisms. J. Microbiol. Methods 12,183-187.

Gooday, G.W. 1990. Physiology of microbial degradation of chitin and chitosan. Biodegradation 1, 177-190.

Hedrick, S.A., Bell, J.N.., Boiler, T. and C.J. Lamb. 1988. Chitinase cDNA cloning and mRNA induction by fungal elicitor, wounding, and infection. Plant Physiol. 86,182-186.

Hood, M.A. 1990. Comparison of four methods for measuring chitinase activity and the application of the 4-MUF assay in aquatic environments. J. Microbiol. Methods 13, 51-160.

Hsu, S.C. and J.L. Lockwood. .1975. Powdered chitin agar as a selective medium for enumeration of Actinomycetes in water and soil. Appl. Microbiol. 29, 422-426

Inbar, J and I. Chet. 1991. Evidence that chitinase produced by Aeromonas caviae is involved in the biological control of soil-borne plant pathogens by this bacterium. Soil Biol. Biochem. 23, 973-978.

Jones, J.D.G., K.L.Grady, T.V.Suslow, and J.R.Bedbrook. 1986. Isolation and characterization of genes encoding two chitinase enzymes from Serratia marcescens. EMBO J. 5: 467-473.

King, E.O., Ward, M.K. and D.E. Raney. 1954. Two simple media for the demonstration of pyocyanin and fluoreescin. J. Labor. Clin. Med. 44, 301-307.

Koby, S., Schickler, H., Chet, I. and A.B. Oppenheim. 1994. The chitinase encoding Tn7-based chiA gene endows Pseudomonas Jluorescens with the capacity to control plant pathogens in soil. Gene 147,81-83.

Kovach, M.E., Phillips, R.W., Elzer, P.H., Roop II, R.M. and K.M. Peterson. 1994. pBBRIMCS: A broad-host range cloning vector. Biotechniques 16, 800-802.

Malik, A., Wenuganen, S., Suwanto, A. and B. Tjahjono. Cloning, DNA sequence and expression of Aeromonas caviae chitinase gene. Molec. Biotech. (in press)

Oka, A., Sugisaki, H. and M. Takanami. 1981. Nucleotide sequence of the Kanamycin resistance transposon Tn905. Mol. Biol 147: 217-226.

Oppenheim, A. B. and I. Chet. 1992. Cloned chitinases in fungal plant pathogen control strategies. Trends Biotechnol. 10,392-394.

Sambrook, J., Fritsch, E.F. and T. Maniatis. 1989. Molecular cloning. Cold Spring Harbor Laboratory Press. Cold Spring Harbor. New York. USA 
Heterologous expression of a chitinase gene from Aeromonas caviae - Amarila Malik el al.

Sitrit, Y., Vorgias, C.E., Chet, I. and A.B. Oppenherm. 1995. Cloning and primary structure of the chiA gene from Aeromonas caviae. J. Bacteriol. 177, 4187-4189

Sundheim, L., A.R. Poplawsky and A.H. Ellingboe. 1988. Molecular cloning of two chitinase genes from Serratia marcescens and their expression in Pseudomonas species. Physiol. Mol. Plant. Pathol. 33: 483-491.

Suwanto, A. and S. Kaplan. 1992. A self-transmissable narrow-host range endogenous plasmid of Rhodobacter sphaeroides 2.4.1: Physical structure, incompatibility determinants, origin of replication, and transfer function. J. Bacteriol. 174, 1124-113

Wirth, S.J. and Wolf, G.A. (1990. Dye-labelled substrates for the assay and detection of chitinase and lysozyme activity. J Microbiol. Methods 12,197-205. 